BNL 50783

\title{
ANNUAL HIGHLIGHTS ENVIRONMENTAL PROGRAMS OF THE DEPARTMENT OF ENERGY AND ENVIRONMENT
}

\section{Bernard Manowitz} Associate Chairman

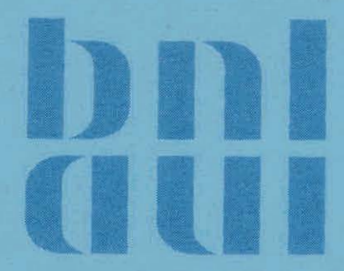

December 1977

BROOKHAVEN NATIONAL LABORATORY ASSOCIATED UNIVERSITIES, INC. UNDER CONTRACT NO. EY-76-C-02-0016 WITH THE UNITED STATES DEPARTMENT OF ENERGY 


\section{DISCLAIMER}

This report was prepared as an account of work sponsored by an agency of the United States Government. Neither the United States Government nor any agency Thereof, nor any of their employees, makes any warranty, express or implied, or assumes any legal liability or responsibility for the accuracy, completeness, or usefulness of any information, apparatus, product, or process disclosed, or represents that its use would not infringe privately owned rights. Reference herein to any specific commercial product, process, or service by trade name, trademark, manufacturer, or otherwise does not necessarily constitute or imply its endorsement, recommendation, or favoring by the United States Government or any agency thereof. The views and opinions of authors expressed herein do not necessarily state or reflect those of the United States Government or any agency thereof. 


\section{DISCLAIMER}

Portions of this document may be illegible in electronic image products. Images are produced from the best available original document. 
BNL 50783

UC-11

(Environmental Control Technology

and Earth Sciences - TID-4500)

\title{
ANNUAL HIGHLIGHTS ENVIRONMENTAL PROGRAMSWASTER OF THE \\ DEPARTMENT OF ENERGY AND ENVIRONMENT
}

\author{
Bernard Manowitz \\ Associate Chairman
}

December 1977

This report was prepared as an account of work
sponsored by the United States Govemment. Neither the
United States nor the United States Department of
Energy. nor any of their employees, nor any of their
contractors, subcontractors, or their employees, makes
any warranty, express or implied, or assumes any legal
llability of responsibility for the accuracy, completeness
or usefulness of any informatinn, apparatus, producl or
process disclosed, or represents that its use would not
infringe privately owned rights.

$0^{13^{60^{0}}}$

BROOKHAVEN NATIONAL LABORATORY

ASSOCIATED UNIVERSITIES, INC.

UPTON, NEW YORK 11973 
NOTICE

This repurt was prepared ao an aocount of work sponsored by the United States Government. Neither the United States nor the United States Department of Energy (DOE), nor any of their employees, nor any of their contractors, subcontractors, or their employees, makes any warranty, express ur implied, or assumes any legal liahility or reoponsibility for the accuracy, completeness or usefulness of any information, apparatus, product or process disclosed, or represents that lts use would uul inlinge privately owned rights.

Printed in the United States of America Available from

Nationd Technical Information Service

U.S. Department of Commerce

5285 Port Royal Road

Springfield, VA 22161

Price: Printed Copy $\$ 6.00$; Microfiche $\$ 3.00$

May 1978

760 copies 


\section{Contents}

Abstract . . . . . . . . . . . . . . . . . . . . . . . iv

I. Introduction .......................... 1

II. Organization . . . . . . . . . . . . . . . . . . . 3

III. Atmospheric Sciences Division . . . . . . . . . . . . . . . 7

IV. Land and Freshwater Environmental Sciences Group . . . . . . . . . . 43

V. Oceanographic Sciences Division . . . . . . . . . . . . . 61 
Environmental Sciences is one of the four areas comprising the Department of Energy and Environment at Brookhaven National Laboratory. It carries out a wide range of activities in atmospheric sciences, oceanographic sciences, and land and freshwater environmental sciences. The Analytical Chemistry Group is also attached to this area. In general, these programs are concerned with identification and measurement of pollutants introduced into the environment by energy-related activities and the evaluation and prediction of the effects or potential effects of these pollutants on the environment.

This first highlights report for Environmental Programs covers the year 1977 and describes the objectives and funding levels of each of the programs, major accomplishments during the year, planned future activities, and current publications. 
I. Introduction

Environmental Programs is a broad-based segment of the Department of Energy and Environment made up of some 35 individual programs covering a wide range of activities in the atmospheric, oceanographic, and terrestrial ecology areas. While the majority of these are supported by the Department of Energy's Division of Biomedical and Environmental Research, a significant number are supported by other governmental and private agencies. In general, these programs are involved with the study of pollutants resulting from the production of energy and their effects or potential effects on the environment. Programs in meteorology and plume dispersion have been conducted since the inception of the Laboratory in 1946. Early programs were developed for tracing plumes from the tall stacks of fossil-fuel burning power plants. The interest has broadened steadily over the years to the present time, where current programs include major participation in the direction and implementation of MAP3S (the Multistate Atmospheric Power Production Pollution Study), including both field and modeling studies related to atmospherlc pollutants in the Northeastern United States, field and analytical study of the meteorology of the coastal land-sea interface, development of long-distance tracer systems for following movements of air masses, the related instrumentation, Instrument systems for the measurement of a series of pollutants at amblent levels in real time, and laboratory and field studies on the collection and behavior of aerosol particulates, including work on the speciation and quantiflcation of sulfate particulates. In support of the field programs, a fully-instrumented twin-englned Britten-Norman Islander is maintained for the exclusive use of the Atmospheric Sciences Division. Indi*vidual programs and current progress are discussed briefly in the section on the Atmospheric Sciences.

Programs in Oceanographic Sciences were initlated in 1973. The general objective of the program is to assess the potential impact of energy-related activities (reactor releases, oll spills, etc.) on the Northeast coastal zone and 1ts biota. Efforts are expended to understand transport and diffusion processes, particularly in the coastal boundary layer, and to couple such understanding with studies of important blological processes that are occurring. 
Biological emphasis is on the dynamics of the lower trophic level. There is a high degree of collaboration with other oceanographic laboratories in the Northeast.

Current programs include studies of coastal transport and diffusion, primary production and ut1lization, food chain dynamics, larval fish mortality, and NSF-sponsored studies on Coastal Upwelling Ecosystems Analysis (CUEA) and PROBES studies of nutrient dynamics and ecosystems analysis in the Bering Sea.

The earliest program to be instituted in the Land and Fresh Water Environmental Sciences was the Upland Recharge Project, designed to provide an ecologically-sound method of recharging water and nutrients to the envirumueul from sewage and septage streams. The project was instituted as part of the Ecology program of the Biology Department. It was transferred to the Department of Applied Science in 1973, and has developed to the point where 1ts successful application can be demonstrated.

A capability for the study of environmental virology has been established both to understand the behavior of viruses in the systems under study at the Laboratory and other problems of human virus distribution in the environment. Another major program is the study of the effects of acid rain on forest ecosystems and on selected crops. 
II. Organization

The programs in Environmental Sciences at Brookhaven National Laboratory are organized as a major division of the Department of Energy and Environment, under the direction of Bernard Manowitz, Associate Chairman of the Department. This is shown in the organizational chart in Figure 1. Figure 2 shows the units that have been organized to carry out these programs. These are the Atmospheric Sclences Division, with Dr. Paul Michael as Division Head and Dr. Leonard Newman as Associate Division Head, with speciflc responsibility for Atmospheric Chemistry; the Oceanographic Sciences Division with Dr. John J. Walsh as Division Head, and the Land and Fresh Water Environmental Sciences Group with Dr. George R. Hendrey as Group Leader. Also included is the Analytical Chemistry Group with Dr. Leonard Newman as Acting Group Leader. This latter group is heavily involved in providing analytical chemistry support to Environmental Programs, but it also provides this service for other Divisions and Departments throughout the Laboratory, as requested.

Currently, Environmental Programs is comprised of approximately 115 people, with 30 of these on the Scientific Staff. The total budgetary support is at a level of $\$ 5,500,000$ for Fiscal Year 1978 . 


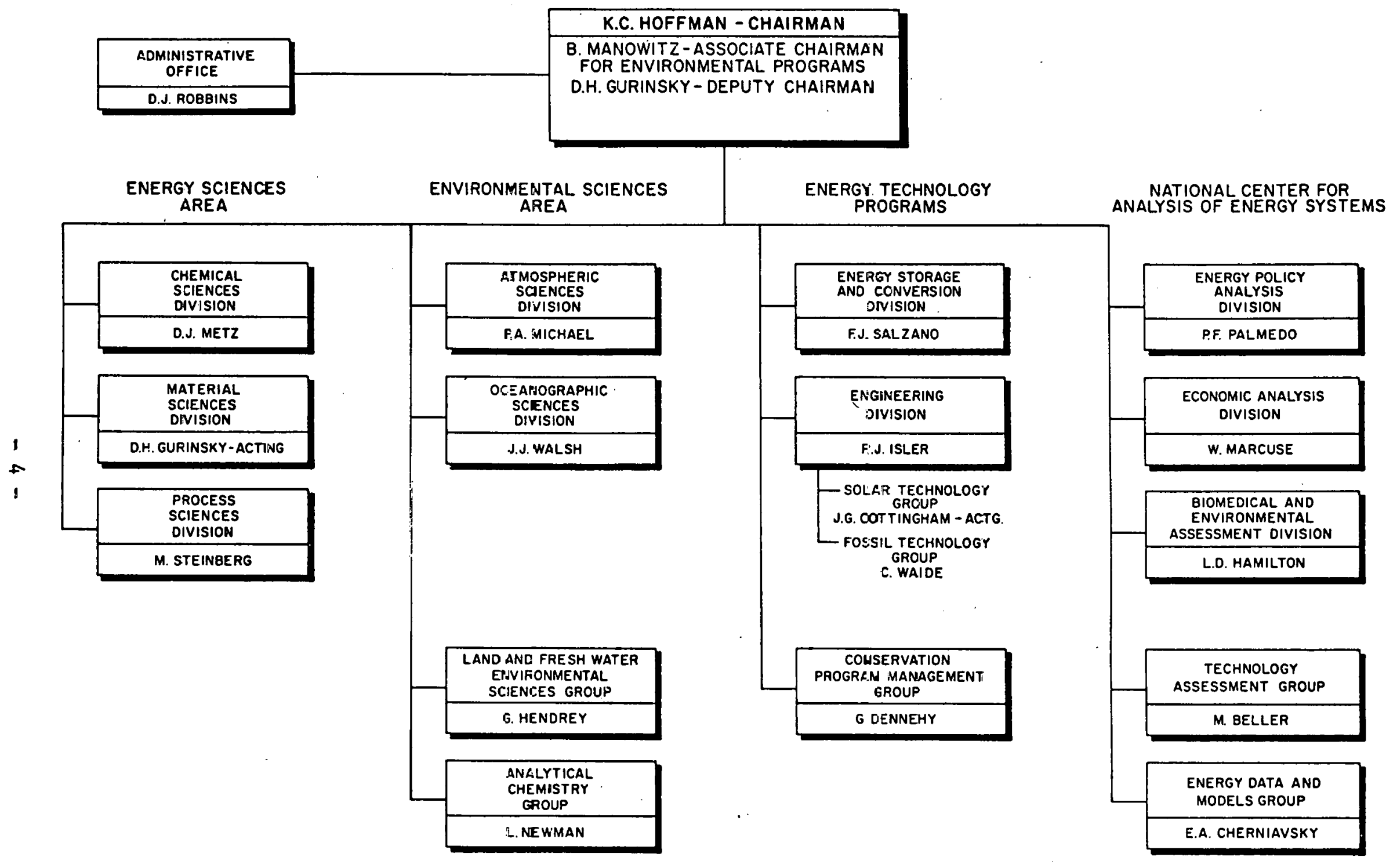

Figure 1. Department of Energy and Emvironment, Brookhaven National Laboratory. 


\section{DEPARTMENT OF ENERGY \& ENVIRONMENT}

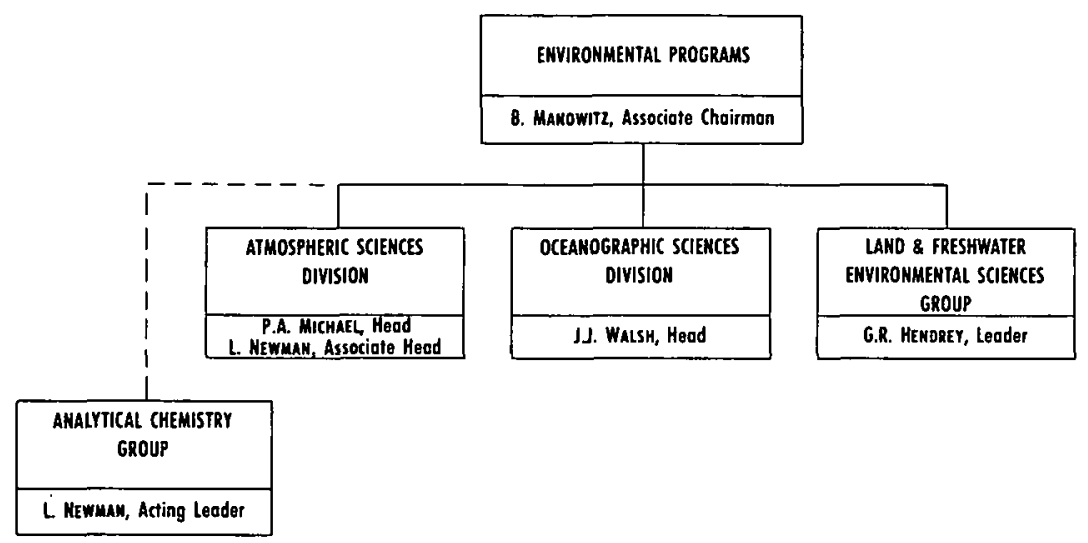

Figure 2 Department of Energy and Environment

Environmental Programs. 


\section{THIS PAGE \\ WAS INTENTIONALLY \\ LEFT BLANK}


III.

Atmospheric Sciences Division

Paul A. Michael

Division Head

Program Objectives . . . . . . . . . . . . . . . . . . 8

Highlights of 1977 . . . . . . . . . . . . . . . . . 9

Major Activities Planned . . . . . . . . . . . . . . . . . 9 9

Scope of Projects . . . . . . . . . . . . . . . . . . . . 11

Publications . . . . . . . . . . . . . . . . . . . 29 
III. Atmospheric Sciences Division

A. Program Objectives

Most of the research in the Atmospheric Sciences Division is aimed at the development of the scientific knowledge needed to realistically evaluate the effects of energy production upon air quality. The activities include field experiments, laboratory studies, instrument and measurement technique development, and theoretical studies and modeling. Support activities include weather forecasting, data management, and data processing. The disciplines represented on the staff include meteorology, chemistry, physics, engineering, mathematico, and computer science.

A major fraction of the research is coordinated through the MultiState Power Production Pollution Study (MAP3S). This program, in which several DOE laboratories and contractors are involved, has as its primary goal the development of the capability to predict the effect of changes in coal utilization patterns on the ambient concentrations of sulfur oxides in the Northeastern United States. The projects which are outlined in section $D$ that are part.of the MAP3S are: MAP3S Modeling and Analysis, MAP3S Data Management, Transport and Transformation Experiments, Atmospheric Diagnostics, Ambient Aerosol Determination, and Aircraft operations. As partially indicated by the project ti,ties, MAP3S research includes the atmospheric chemistry of sulfur oxides, mesoscale transport, measurement technique development, model development, the characterization of pollutant distributions in the Northeast, and the establishment and operation of a data base for the use of MAP3S participants. The coastal meteorology program is aimed at the identification and quantification of coastal processes that affect the transport and diffusion of pollutants over the ocean and across the land-sea interface. Methods development work is focused upon instrumentation for the detection of sulfurhexafluoride and perfluorocarbons that are used as tracers in the atmosphere, and upon the use of spectral tcchniques for the quantitative measurement of various pollutants. There is a program of laboratory experiments on the basic chemical and physical properties of aerosols. Considerable interaction exists with others at BNL. Air quality calculations are done as a part of the assessments of encrgy impact on the envirunment performed in the Regional Studies program of the National Center for the Analysis of Energy Systems. The coastal meteorology program is closely coordinated with the physical oceanography research performed within the Oceanographic 
Sciences Division, precipitation chemistry studies have been done in conjunction with $t$ and and Fresh Water Environmental Sciences Group. Callaboration with the Solar Technology Group includes the operations incident to solar radiation monitoring equipment and the statistical analyses of archived data. The weather forecasting operation acts as a service to general Laboratory operations.

B. Highlights of 1977

A Britten Norman Islander twin-engine aircraft on long-term lease was equipped, certified by $\mathrm{FAA}_{3}$, and put into operation.

The first MAP3S characterization measurements were performed; these included airborne wide-area measurements and intensive temporal series of pollutant measurements at BNL. The latter measurements were also coordinated with the New York Aerosol Study, a program of measurements throughout the metropolitan New York region. Other participants in that study were New York University Medical Center, Yale, E.M.L., and Interstate Sanitation Commission.

There was participation with ANL, PNL, and others in a major boxbudget field experiment in central Indiana.

A set of comprehensive alr/sea interaction measurements were performed in cooperation with the COBOLT experiment.

An $\mathrm{SF}_{6}$ continuous real-time detector was put into operation in conjunction with atmospheric tracer studies.

An assessment of the impact of fossil fuel burning upon air quality and health was made as a part of the NAS Committee on Nuclear and Alternative Energy Systems (CONAES) study. This involved the linking of an air quality model with power plant site informallon, meteorological data, population distribution, and an assumed linear dose response function.

C. Major Activities Planned for 1978

The MAP3S characterization studies will be continued; measurements w11l include temporal series at BNL, horizontal mesoscale aircraft measurements and vertical distribution of pollutants.

Measurements of the pall from the Northeast megalopolis will be made over the Atlantic Ocean in order to determine chemical reaction rates in a source-free region. 
A link between the Nationa ${ }^{-1}$ eather Service $^{-}$computers at Suil land and the BNL computers will be made operational and this will allow improved planning of experiments and more prompt analysis.

Key coastal-diffusion experiments will be performed with emphasis on the modification of the boundary layer as air flow moves inland.

It is expected that capability for gaseous nitric acid measurements and measurement of sulfate in real time will reach field application stage. A high-volume aerosol sampler which will resolve into four size ranges will be operational.

An $\mathrm{SF}_{6}$ tracer experiment will be performed in conjunction with the EPA's Sulfur Transformation and Transport Experiment (STATE). 
D. Scope of Projects

$-11-$ 
Title: Evaluation of Vapor Taggants and Substrates

for the Tagging of Blasting Caps

FY 77: $\$-0-$

FY 78: $\$ 75,000$
Principal Investigator(s):

Russell N. Dietz

Gunnar I. Senum

Sponsor: Aerospace Corp./USAF

The purpose of this program is the evaluation of vapor taggants which would be used for the vapor tagging of electric blasting caps. This would allow the predetonation detection of otherwise undetectable hidden explosives. Most of these explosives are detonated by electric blasting caps. The vapor taggant would be Impregnated into a suitable substrate which would replace the present blasting cap and enclosures. Any attempted removal of the taggant would result in the destruction of the blasting cap. The vapor taggant would be slowly released (1-10 nanoliters/min) from the substrate and would subsequently be detected by an electron capture detector.

The experimental program consists of preparing the various taggant/substrare combinations as dummy blasting caps and following the taggant emission rates gravimetrically and chromatographically periodically over a period of several months. The various taggant/substrate pairs are evaluated by chromatographically determining the taggant concentrations from various simulated scenarios, e.g., tagged blasting caps enclosed inside plastlc bags, cans, pipe bombs, etc., which are placed inside boxes, briefcases, suitcases, etc. From these scenarios relative attenuation factors will be derived for the detection of vapur taggants in various scenarios and the effectiveness of tagged caps realisticallÿ evaluated.

A theoretical model has been derived which predicts the taggant emission rate from tagged blasting caps. This has been verified with several/taggant substrate blasting cap combinations. The model will allow the prediction of the effective tagged cap lifetime. 
Title: Collaborative Project for Inter-Laboratory Data Exchange

FY 77: $\$ 25,000$

FY 78: $\quad \$ 25,000$
Principal Investigator(s):

C.M. Benkovitz

Sponsor: Division of Environmental Inpacts (DOE)

DOE objectlves require the unprecedented exchange and utilization of large amounts of computerized descriptive information and numeric data among the national laboratories. Regional and nationwide analyses and assessments in support of DOE's energy and environmental policy formulation are the ultimate objective of these programs. Resource sharing and standardization of computerreadable files and programs for exchange purposes are finding significant increases in the efficiency with which these analyses are carried out. To comply with these demands in a timely and cost-effective manner, the InterLaboratory Working Group for Data Exchange (IWGDE) was formed with the following mission:

1. The share expertise in machine utilization of information and data.

2. To establish both short-term and long-term objectives for resource sharing in data management.

3. To establish, test, and implement practical data exchange formats.

4. To examine the laboratories' present data-base management systems and practices, and develop appropriate mechanisms for interfacing among these systems.

5. To make long-term recommendations for a Data Base Management System, and

6. To recommend administrative guidelines for exchange of data and programs.

Development of this program at each laboratory should result in the evolution of a highly cost-effective approach to inter-laboratory cooperation and collaboration in making the regional character of many research programs conform to the need for assessment of energy impacts on a nationally-integrated basis. It is building on a strong expertise and extensive investmant already available in the DOE laboratories in the data-management field and is being tailored to the needs of users for timeliness, high quality, and easy integration into modeling and policy-oriented projects. 
Title: Sulfate Emissions from Fossilfueled Combustion Sources

FY 77: $\$ 75,000$

FY 78: $\$ \$ 0,000$
Principal Investigator(s):

Russe11 N. Dietz

Sponsor: E P A

Any voluntary or legislaced action taken lo cuntrol sulfates should bc based at least in part on a thorough knowledge of the character of primary sulfates (i.e., $\mathrm{H}_{2} \mathrm{SO}_{4}$ and water soluble sulfate salts), their emission rates from power plant, institutional, and industrial boilers as well as from apartment and home heating units, and an understanding of the variables which primarily govern the magnitude of those emissions. The overall goal of this program is to provide this information using proven reliable flue gas sampling techniques.

A carefully planned program is being followed to assure the quality of the information obtained in accomplishing the program goals. A reliable sampling method based on a controlled condensation system (CCS) for separately collecting particulates (including water soluble sulfates) and sulfurlc acld has been validated in the laboratory under simulated flue gas sampling conditions, documented for performance in actual field sampling tests, and compared to the recommended Modified EPA Method 6 which is based on the principle of preferential absorption of $\mathrm{H}_{2} \mathrm{SO}_{4}$ in isopropyl alcohol (IPA) solution. Problems were encountered with the oxidation of $\mathrm{SO}_{2}$ by an unknown contaminant in the IPA as well as some difficulty in stripping out all of the $\mathrm{SO}_{2}$ prior to determination of acid levels. In addition, simultaneous determinations with both methods showed some discrepancies. Total sulfate levels with the IPA method were about 3 times higher than the CCS when sampling at comparative locations at an oil fired power plant. Laboratory and field evaluation of Brookhaven modifications to the Modified EPA Method 6 are being conducted and comparative tests with CCS will be made. 
Title: Evaluation of Recommended Meteorological Measurements and Diffusion Models for Coastal Nuclear Power Plant Sites

FY 77: $\$-0-$

FY 78: $\$ 35,000$
Principa1 Investigator(s):

G. Raynor

S. SethuRaman

Sponsor: N R C

This study is designed to examine currently recommended meteorological measurement programs and atmospheric transport and diffusion prediction methods for nuclear power plants to determine their adequacy for plants located in coastal zones where meteorological conditions are more complex than at inland sites. A literature review w111 be conducted to determine available knowledge on coastal meteorological processes and their influence on diffusion. Data from experimental diffusion measurements will be examined and related to associated meteorological conditions. The effect on diffusion and the fate of effluents of temporally varying factors, such as sea breezes, and spatially changing factors, such as internal boundary layers, will be evaluated. The data will then be used to test the adequacy of presently used diffusion models, to determine what changes and improvements, if any, are needed for acceptably accurate prediction under coastal conditions and to determine what meteorological measurements are necessary as input to the prediction models. Appropriate changes in measurement requirements and prediction methods will be recommended. If current knowledge is found inadequate to meet these goals, recommendations for furcher research will be. made. 
Title: Sulfuric Acid Release in Maritime Spill Accidents

FY 77: \$-0 -

Principal Investigator(s):

I. Tang

FY 78: $\$ 250,000$

Sponsor: U.S. Coast Guard/DOT

Concentrated sulfuric acid and oleum are among the several hazardous chemicals which are transported in large quantities on U.S. waterways. There have been incidents in the past when hundreds of tons of sulfuric acid were accidentally discharged into water during marine mishaps. Because of the high exothermicity of sulfuric acid when mixed with water and the high volatility of oleum, a substantial fraction of the spilled acid could become airborne in the form of an acid mist, thereby posing threats to the safety of the personnel directly involved in the accident, as well as the general public in certain cases. The objective of this research program is to quantitatively characterize the spill of sulfuric acid on water under conditions likely to occur in marine accidents. Specific areas of interest include (1) an investigation of the formation mechanisms for sulfuric acid aerosols resulting from a spill, (2) the growth of acid cloud formed during and immediately after a spill, and (3) the exothermic and turbulent mixing of acid with water in the vicinity of a release source. Pertinent data will be obtained to provide a basis for the U.S. Coast Guard to formulate emergency response procedures and make realistic environmental impact statements concerning a given acid spill. 
Title: Sulfate Formation in Oil Fired Power Plant Plumes

FY 77: $\$ 160,000$

FY 78: $\$ 140,000$
Principal Investigator(s):

R. Dietz

R. Garber

L. Newman

Sponsor: EPRI/ESEERCO/LILCO

This research program was undertaken to provide an understanding of the formation of sulfate in the emissions from oil-fired power plants and the conditions controlling this formation. This program is being carried out on two parts. One part is a detailed study of the emissions from an oil-fired power plant and how plant operating conditions affect the composition of these emissions. The emissions study requires sampling the power plant exhaust gases at several locations in the plant under a variety of plant operating conditions. The resultant samples are analyzed for sulfate, sulfuric acid, sulfur dioxide, particulate loading, oxygen, carbon monoxide, carbon, and the principal metals in the particulates. The results from this part of the program are expected to show the conditions which affect the in-situ formation of sulfate and sulfuric acid.

The second part of the program is a study of the mechanisms governing the change of sulfur species in the plume of the same power plant as the plume travels downwind for up to 50 to $100 \mathrm{~km}$. An aircraft equipped with a special filterpack assembly and certain real-time monitors $\left(\mathrm{SO}_{2}\right.$, temperature, humidity, etc.) traverses the plume in the crosswind direction at several distances from the stack--typically $1 / 2$ to 10 miles. Samples are analyzed primarily for $\mathrm{SO}_{2}$ and total sulfate in order to document the mechanisms of chemical transformation and/. or particulate fallout. The samples are collected under various meteorological conditions which may have an influence on the plume chemistry. 
Title: Real-Time Measurement

FY 77: $\$ 120,000$

Principa1 Investigator(s):

R. F. Adamowicz

FY 78: $\$ 130,000$

S. Schwartz

Sponsor: Division of Biomedical and Environmental Research (DOE)

The objectives of this program are the development and novel utilization of state-of-the-art spectroscopic techniques that allow for real-time, simultaneous measurement of a variety of atmospheric pollutants resulting from energy production that are present in gaseous, aerosol, and particulate phases such as sulfuric acid, sulfate salts, $\mathrm{OH}$ and oxi-organic radicals, $\mathrm{NH}_{3}, \mathrm{SO}_{2}, \mathrm{NO} / \mathrm{NO}_{\mathrm{x}}, \mathrm{O}_{3}$, aliphatic and aromatic hydrocarbons. The development and application of real-time instrumentation for in-situ characterization and determination of critical species will dramatically advance understanding of the homogeneous and heterogeneous chemical transformations of these energy-related pollutants as well as their transport.

Three spectroscopic systems that would allow for ultrasensitive simultaneous measurement of a number of different pollutants and which require no premeasurement treatment of the samples are, an intracavity laser Raman system, an optoacoustic system at $\mathrm{CO}_{2}$ laser wavelengths and a UV resonance fluorescence. The Laser Raman and opto-acoustic systems are currently being breadboarded. Theoretical calculations and preliminary tests indicate a practical sensitivity limit of $0.1 \mathrm{ppb}$ pollutant concentration for both systems. It is anticipated that laboratory prototype systems will be completed this fiscal period and sufficient measurements taken so that the design criteria for fieldable instruments may be ascertained. 
Ti.tle: Fragile Molecules

FY 77: $\$ 100,000$

Principal Investigator(s):

R. Tanner

FY 78: $\$ 110,000$

Sponsor: Division of Basic Energy Sciences (DOE)

The long-term goals of this program are to devise and develop fundamentally new analytical methods of high sensitivity and selectivity for the determination of traces of reactive substances in the environment based on derivatization-chromatographic separation specific-element detection techniques. Since many substances of interest are reactive under analysis conditions, derivatization is used to convert the reactive or otherwise fragile substance, to a stable one which can be separated from interferences and delivered quantitatively to a detector. Chromatographic techniques (gas, 1iquid, thin layer, ion exchange) are well-established methods for increasing analytical specificity by separating co-derivatized substances and other interferents from the derivative of interest. Element-specific detectors, whose response is keyed to a single element or moiety, increase sensitivity by orders of magnitude for substances containing that element. This reduces the detector response for even gross amounts of potential interferences and simplifles the separation technology. The derivatization-chromatography element specific detection principle is sufficiently broad and promising as to be potentlally applicable to analysis of species of dynamically-varying concentration in the aqueous environment (i.e., phosphate, nitrate, nitrite) as well as in the atmosphere (gaseous ammonia, nitric acid, sulfate in airborne particles). 
Title: Aerosol Chemistry and Dynamics

FY 77: $\$ 100,000$

Principal Investigator(s):

I. N. Tang

FY 78: $\$ 120,000$

Sponsor: Division of Biomedical and Environmental Research (DOE)

Aerosols are suspensions of particulate matter in a gaseous medium and play an important role in many atmospheric processes. The presence of aerosols in the atmosphere directly influences local vislbility, regional climatic changes, and, on a larger scale the total radiation balance of the earth. Because of their high concentration and large surface-to-volume ratio especially in urban and industrial areas, airborne particles readily serve as a sink for many harmful gaseous pollutants by providing sites for condensation, sorption, or catalytic reactions. Moreover, since the particles themselves are frequently products from pollution sources, their behavior with respect to transport and deposition is of considerable ecological significance.

The objective of this research program is to elucidate the chemical and physical processes which govern the dynamic behavior of an aerosol system. Since processes such as condensation, evaporation, dissolution, crystallization, coagulation, and surface reactions directly affect the chemical composition and particle-size distribution of an aerosol, it is necessary to delineate and measure the parameters of these processes under specific conditions. This work is currently underway at BNL. In addition, research is being initiated to undertake a systematic study of the chemical reactions which are precursory to the formation of atmospheric aerosols.

The results of this continuing research program are expected to provide a better understanding of the basic mechanisms of pollutant transformation and transport in the atmosphere. In addition, data on condensational aerosol growth are becoming increasingly important for health-effect evaluations of various hygroscopic aerosols in the environment as a result of accelerated energy consumption. 
Title: Aerosol Measurements and Microphysics

FY 77: $\$ 100,000$

FY 78: $\$ 110,000$
Principal Investigator(s):

W. Marlow

Sponsor: Division of Biomedical and Environmental Research (DOE)

Aerosols are principal agents: by which air pollution has its impact on man, animals, plants, and the atmosphere. Little is known about their origin, evolution (either physical or chemical), atmospheric interactions, or eventual removal processes. The efforts under this program are concerned with the development of both instrumentation for field studies of the atmospheric aerosol and methods for the analysis and interpretation of these measurements. The planning, and design of this instrumentation as well as its utilization in field studies is done with considerable input and cooperation from other Atmospheric sciences groups. The analytical work relates to instrumental methods and measurement methodology while the interpretive work draws largely upon fundamental chemical physics. 
Title: Aircraft Operations

FY 77: $\$ 213,000$

FY 78: $\$ 185,000$
Principal Investigator(s):

R. Garber

Sponsor: Divison of Biomedical and Environmental Research (DOE)

A twin engine-aircraft has been leased for exclusive use to carry out research projects which are part of the Atmospheric Sciences programs at Brookhaven National Laboratory. The alrcraft is used for atmospheric sampling and analysis experiments. Routine observation of the horizontal and vertical distribution of pollutants which are conducted for the MAP3S program require about one half of its scheduled flight time. Plume studies which are part of the MAP3S program require about one quarter of the scheduled flight time. The remaining scheduled flight time is used principally for cooperative atmospheric studies with observation teams from other organizations which are part of the MAP3S program. Other BNL Atmospheric Sciences programs may obtân flight time on this aircraft on a cost-recoverable basis.

For certain studies which are conducted for the MAP3S program and for other Atmospheric Sciences programs, utilization of a second small aircraft is necessary. Additional aircraft will be obtained on a short-term rental basis and outfitted with easily-installed equipment for the purposes of the specific study.

As part of Aifcraft Operations a program of equipment testing, calibration, and modification is required to maintain an effective atmospher1c sampling and analysis system for the aircraft. 
Title: MAP3S Data Management

FY 77: $\quad \$ 100,000$

Principa1 Investigator(s):

C. Benkovitz

FY 78: $\$ 150,000$

Sponsor: Division of Biomedical and Environmental Research (DOE)

A major portion of the MAP3S program is concerned with the collection, evaluation, and codification of both newly-measured and selected historical data that pertain to the distribution and evolution of energy conversion-related pollutants over the Greater Northeast. The initial purpose is to collect sufficient reliable information to assess the extent and severity of the present $\mathrm{SO}_{2}$ /sulfate atmospheric burden over the region. These data will provide preliminary objective answers to questions on the spatial and temporal variability of atmospheric sulfate aerosol, and will supply preliminary estimates of the relative impacts of particular source regions. A continuing purpose is to build a readily-accessible data bank (this to include supporting source inventory and meteorological information) against which submodel parameterization schemes and, eventually, full-parameterized, regional-pollutant transport and transformation simulations can be tested. A longer-range goal will be to provide baseline air-quality data for the Greater Northeast to which future assessment of regional atmospheric environmental impacts attributable to new energy technologies may be referred. 
Title: Modeling and Analysis (MAP3S)

FY 77: $\$ 160,000$

Principal Investigator(s):

R. E. Meyers

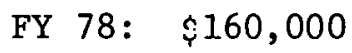

Sponsor: Division of Biomedical

and Environmental Research (DOE)

This project is designed to perform five critical modeling and analysis functions and one research-coordination function for the Division of Biomedical and Environmental Research (DBER) Multistate Atmospheric Power Production Po11ution Study (MAP 3S).

The modeling and analysis functions consist of development of: 1) An advanced three-dimensional Eulerian-grid pollution model treating nonlinear chemistry, lone-distance transport and diffusion of sulfur compounds, $\mathrm{NO}_{x}, \mathrm{O}_{3}$, and related chemicals on the regional scale; 2) a "variational" diagnostic threedimensional meteoroligical analysis model capable of objectively resolving inversions and fronts on the regional and subregional scale; 3) advanced plumelaboratory reaction models incorporating lumped chemistry and the major effects of turbulent mixing upon chemical reactions; 4) a computer link from BNL to the Nationa1 Weather Service at Suitland, Md., to supply MAP3S with c1mely meteuru= logical data for experiments and modeling; and 5) the design of field experiments, including establishment of aircraft data requirements and quality assurance such as calibration flights and intercomparison programs, to test and further develop the modcls.

$T_{\text {ii }}$ addition, R. E. Meyers will provide the MAP3S Numerical Modeling Working Group coordinating functions, consisting of chairmanship of the MAP $3 S$ Modeling Working Group and related duties. 
Title: Transport and Transformation (MAP3S)

FY 77: $\$ 375,000$

Principal Investigator(s):

P. Michae1

L. Newman

FY 78: $\$ 400,000$

Sponsor: Division of Biomedical and Environmental Research (DOE)

This program is a part of the Multistate Atmospheric Power Production Pollution Study (MAP3S) of the Department of Energy (DOE), Division of Biomedical and Environmental Research (DBER). The purpose of this study is to develop the ability to assess the effects of the use of fossil fuel upon health and the environment. This ability will require the development of simulation models. The overal1 effort is interdisciplinary and involves other DOE laboratories, other contractors, and possibly other agencies.

This particular effort is aimed at obtaining experimental results to: (1) Test hypotheses used in simulation models; (2) develop an understanding of mechanisms so that proper parameterization may be used in models; and (3) provide data for the testing of integrated models. In particular, measurements will be made of the vertical and horizontal distributions of sulfates. Studies of the transformation of sulfur dioxide to sulfate will be made in the atmosphere and there will be participation in large-scale field experiments. 
Title: Atmospheric Diagnostics

FY 77: $\$ 254,000$

Principa1 Investigator(s):

L. Newman

FY 78: $\$ 275,000$

R. Tanner

Sponsor: Division of Biomedical and Environmental Research

(DOE)

To study the generation, transport, transformation, and removal processes of pollutant species in the atmosphere requires the development of fundamencally ntw analytical methods as well as implementation of existing methods for measuring the identities and amounts of these pollutants. The Atmospheric Diagnostics program is designed to develop and implement analytical methods for studying the chemical and physical properties of airborne gaseous and aerosol constituents and their evolution under the dynamically-changing meteorological conditions of the ambient atmosphere. Constituents include gaseous species (sulfur and nitrogen oxides, ozone, ammonia, nitric acid, hydrocarbons) as well as particulate sulfur, nitrogen, and trace metal compounds classified by particle size. $\Lambda$ reas of interest include urban and power-plane plumes and lieir impact on rural areas, ambient aerosol composition (as a function of particle size) and 1ts seasonal, diurnal, and regional variability, and vertical pollutant composition profiles as they affect long-range transport phenomena.

The overall goal of this program is to develop and/or implement the best methods for determination of specific atmospheric pollutants using continuous or integrated sampling techniques. Major emphasis is on the analytical methods for determination of amblent levels of speciflc oxygenuled sulfur and nitrogen compounds (sulfate, sulfuric acid, nitrate, etc.). These determinations combined with ammonia, strong acid, and size-distribution measurements will lead to better understanding of transformation processes controlling aerosol sulfate and nitrate levels. 
Title: Coastal Meteorology

FY 77: $\$ 200,000$

FY 78: $\$ 210,000$
Principal Investigator(s):

P. Michael

G. S. Raynor

Sponsor: Division of Biomedical and Environmental Research

(DOE)

This study is designed to obtain an understanding of meteorological processes in the coastal region that affect siting, operation, and safety of power-producing and related facilities located either offshore or near a coastilne. The study involves climatological investigations, tracer experiments, wake-effects studies, mesoscale and micrometeorological observations, theoretical studies, and modeling programs.

A major goal of the program is to develop a reliable system for describing diffusion conditions affecting releases from coastal or offshore sites and to predict them from measurable meteorological and surface parameters such as general synoptic situation, type of flow (sea-breeze or gradient), wind and temperature structure, sea-surface roughness, and coastal terrain, Meeting this goal involves an understanding of conditions in the transition region where over-ocean flow is modified by passage over land as well as over the water.

Results of this program will include techniques for the prediction of overocean and coastal wind and temperature fields which not only transport and diffuse pollutants but are involved in air-sea interactions and oceanic processes. They will also include a rating of sites along the U.S. East and Gulf coasts in terms of onshore wind frequency, diffusive capacity, and severe weather prevalence. 
Title: Electron Capture Detector Advancements and

Separation and Concentration Techniques

FY 77: $\$ 118,000$

FY 78: $\$ 130,000$
Principal Investigator(s):

R. Dietz

Sponsor: Division of Biomedical and Environmental Research

(DOE)

Four main areas have been under development, including meteorological tracing instrumentation, sampling and concentration procedurès, chem1cal cunvelsion processes, and development of pollution sources. The meteorological tracing instrumentation has been directed at developing and improving electroncapture chromatographic procedures for the determination of the meteorological tracer gas, sulfur hexafluoride, both for laboratory determination of collected air samples and for portable instruments in the field. Many ambient-level pollutants (for example, $\mathrm{SO}_{2}, \mathrm{H}_{2} \mathrm{SO}_{4}, \mathrm{NH}_{3}$ ) exist at concentrations below current levels of sensitivity for direct instrumental detection methods. Sampling and concentration procedures using perm-selective membrane techniques as well as selective adsorption and volatilization for tracer compounds and ambient air pollutants are under study. Chemical conversion processes for removing oxygen continuously from sampled air (by chemical solutions or gas-phase catalysis) would eliminate interference with the EC detector and allow continuous detection of $\mathrm{SF}_{6}$ or other tracer gases. Trace gas sources for certain air pollutants $\left(\mathrm{H}_{2} \mathrm{~S}, \mathrm{SO}_{2}, \mathrm{NH}_{3}\right)$ at nanoliter per minute levels and ultra-trace sources for meteorological tracer compounds at sub-nanoliter per minute levels are belng fabricated and calibrated by newly developed methods. 
E. Publications 
Publications

Atmospheric Sciences Division

1977

BNL 22262R UNIPOLAR AEROSOL DIFFUSION CHARGING, I: PARTICLE DIELECTRIC

Jan. 1977

CONSTANT AND ION MOBILITY DISTRIBUTION EFFECTS

William H. Marlow

J. Colloid and Interface Science (1n press)

BNL 22345

THE OBSERVED GENERATION AND BREAKING OF ATMOSPHERT. .

Jan. 1977

INTERNAT. GRAVITY WAVES OVER OCEAN

S. SethuRaman

J. Boundary Layer Meteorology (in press)

BNL 22439R PROCESS LIMITING THE OXIDATION OF SULFUR DIOXIDE IN STACK PLUMES

Feb. 1977

Stephen E. Schwartz and Leonard Newman

Pres. at AIChE 70th Meeting, New York City, Nov. 13-17, 1977

J. Environmental Science $\underline{\text { Tech. }} \underline{12}$, No. 1, pp. 67-73 (1978)

BNL 22440 CHEMICAL-ANALYTICAI, TECHNIQUES FOR AEROSOLS

Feb. 1977

Roger L. Tanner and Leonard Newman

Chapter in Fundamentals of Aerosol Science-Recent Development in Applied Aerosol Technologies, Wiley and Sons (in press).

BNL 22441R

SIZE DISCRIMINATION AND CHEMICAL COMPOSITION OF AMBIENT

Feb. 1977 AIRBORNE SULFATE PARTICLES BY DIFFUSION SAMPLING

Roger L. Tanner and William H. Marlow

J. Atmospheric Environment 11, pp. 11-4.3 (1977)

BNL 22442 AEROSOL GROWTH STUDY. II. PREPARATION AND GROWTH

Feb. 1.977 MEASUREMENTS OF MONODISPERSE SALT AERO3OLS

I. N. Tang, H. R. Munkelwitz, and J. G. Davis

J. of Aerosol Science 8, pp. 149-159 (1977) 
Publications

Atmospheric Sciences Division

1977

BNL 22485

TEMPORAL VARIATION OF SUSPENDED ATMOSPHERIC

Feb. 1977

PARTICULATES AT UPTON, L.I., N.Y.

S. SethuRaman and R. M. Brown

Presented at Joint Conf. on Applications Air Pollution

Meteorology, Salt Lake City, Utah, Nov. 28-Dec. 2, 1977.

BNL 22525 PLUME CHARACTERISTICS

Mar. 1977

Leonard Newman

Presented at Aerlal Tech. for Environmental Monitoring,

American Nuclear Society, Las Vegas, Nev., March 7-11, 1977.

BNL 22547R

A STATISTICAL CORRELATION BETWEEN AMBIENT SULFATE CONCENTRATION

Mar. 1977

AND SULFUR DIOXIDE CONCENTRATION, TOTAL SUSPENDED PARTICULATES

AND RELATIVE HUMIDITY FOR 13 EASTERN STATES

Ronald E. Meyers and Edward N. Ziegler

Environmental Science and Technology (in press)

BNL 22565

Mar. 1977

Abstract
OPTICAL-SIZE FEETICLE PENETRATION THROUGH A DIFFUSION PROCESSOR FOR FILTER SAMPLING

W. H. Marlow

Presented at Conf. Industrial Hygiene, New Orleans, La., May 23-27, 1977.

BNL 22566

AEROSOI. GROWTH STUDIES. III. AMMONIUM BISULFATE

Mar. 1977

AEROSOLS IN A MOIST ATMOSPHERE

I. N. Tang and H. R. Munkelwitz

J. Aerosol Sci. 8, pp. 321-330 (1977) 


\section{Publications}

Atmospheric Sciences Division

1977

BNL 22569

Mar. 1977
TRANSPORT OF OZONE ASSOCIATED WITH AN AIR MASS

G. T. Wolff, P. J. Lioy, G. D. Wight, R. E. Meyers, R. T. Cederwall

Presented at 70th Annual Meeting, Air Pollution Control

Assoc. (APCA), Toronto, Ontario, Canada, June 20-24, 1977

and to appear in the procecdingo.
BNL 22576R

Mar. 1977
A MODEL FOR TIL REVERSIBLE WASHOUT OF SULFUR DIOXIDE, AMMONIA AND CARBON DIOXIDE FROM A POLLUTED ATMOSPHERE AND THE PRODUCTION OF SULFATES IN RAINDROPS

Robert Adamowicz

Presented at 70th Annual Amer. Inst. Chem. Engr. Meeting, New York, N.Y., Nov. 13-17, 1977.

J. Atmospheric Environment (submitted)
BNL 22595

Mar. 1977
FACILITATING DATA INTERCHANGE WITH ERDA

Carmen M. Benkovitz

Presented at the VIM 26 Conference, Minneapolie, Minn., Apri1 3-7, 1977.
BNL $22643 \mathrm{R}$ APPLICATION OF ${ }^{110}$ Ag MICROGRAM SULFATE ANALYSIS FOR THE Apr. 1977 SHORT TIME RESOLUTION OF AMBIENT LEVELS OF SIJT.FIIR AFROSOL Joseph Forrest and Leonard Newman Analytical Chemistry 49, No. 11, pp. 1579-1584 (Sept. 1977)
BNL 22685 Apr. 1977
SEPARATION AND ANALYSIS OF AEROSOL SULFATE SPECIES AT AMBIENT CONCENTRATIONS

Roger L. Tanner and Leonard Newman

Presented at the Division of Environmental Chem. Meeting, New York City, April 1976. 
Publications

Atmospheric Sciences Division

1977

BNL 22696

STATISTICAL CORRELATIONS OF THE WAVE-INDUCED

Apr. 1977

ATMOSPHERIC TURBULENCE OVER THE SEA

S. SethuRaman

Presented at the Fifth Conf. on Probability and Statistics

in Atmospheric Sciences, Las Vegas, Nev., Nov. 15-18, 1977.

BNL 22697 AN INVESTIGATION OF LONG-RANGE TRANSPORT OF OZONE

Apr. 1977 ACROSS THE MIDWESTERN AND EASTERN UNITED STATES

George T. Wolff and Paul J. Lioy (Interstate San. Comm., New York

City), Gregory D. Wight (Conn.. Dept. Environ, Protection), and

Ronald E. Meyers and Richard Cederwal1, Brookhaven National Lab.

Atmos. Environment 11, pp. 797-802 (1977)

BNL 2.2717 A COMPARISON OF DIFFUSION FROM A SMALL

Apr. 1977 ISLAND AND A UNDISTURBED OCEAN SITE

Gilbert S. Raynor, Robert M. Brown, and S. SethuRaman

J. Applied Meteorology (In press)

BNL 22815

EFFECTS ON ATMOSPHERIC DIFFUSION OF METEOROLOGICAL

May 1977 PROCESSES IN COASTAL ZONES

Gilbert Raynor

Presented at ASTM Conf. on Air Quality Meteorology and Atmospheric Ozone, Boulder, Col., Aug. 1-6, 1977.

BNL 22816

May 1977

Abstract
TRENDS IN ATMOSPHERIC PARTICULATE CONCENTRATIONS AT $\Lambda$ LOCATION IN THE NORTHEAST UNITED STATES

Robert M. Brown and S. SethuRaman

Presented at the 4 th Joint Conf. on Sensing of Environmental Pollutants, New Orleans, La., Nov. 6-11, 1977. 


\section{Publications}

Atmospheric Sciences 'Division

1977

BNL 22817 CALIBRATION OF A VARIOMETER TO MEASURE VERTICAL VELOCITY

May 1977 FLUCTUATIONS IN THE ATMOSPHERIC BOUNDARY LAYER

S. SethuRaman, R. M. Brown, and G. S. Raynor

Presented at the 4th Joint Conf. on Sensing of Environmental

Pollutants, New Orleans, La., Nov. 6-11, 1977.

RNT. 22842 OPTICAL SIZE DETERMINATION FOR 3 INGLE CUBIC

May 1977 PARTICLES SUSPENDED IN A LASER BEAM

I. N. Tang and H. R. Munkelwitz

J. Colloid and Interface Science (in press)

BNL 22879 METEOROLOGICAL AND CHEMICAL RELATIONSHIPS

June 1977 FROM SEQUENTIAL PRECIPITATION SAMPLES

Gilbert S. Raynor

Presented at the AIChE 70th Annual Meeting: Atmospheric Sulfur Compounds, Formation and Removal Procees, New York City, Nov. 13-17, 1977.

BNL 22914 TECHNIQUES FOR DETERMINING THE CHEMICAL

June 1977 COMPOSITION OF AEROSOL SULFUR COMPOUNDS

L. Newman

Presented at the International Symp. on Sulfur in the Atmosphere, Dubrovnik, Yuguslavia, Sept. 9-13, 1977.

DNL $22914 R$ J. Atmos. Environment. (In press)

BNL 22922

June 1977
UNIPOLAR AEROSOL DIFFUSION CHARGING, II: ION AND AEROSOL POLYDISPERSITIES IN UNIPOLAR CHARGING THE

"DIFFUSION CHARGING MOBILITY ANALYSIS" HYPOTHESIS

William H. Marlow

J. Colloid and Interface Science (in press) 


\section{Publications}

Atmospheric Sclences Division

1977

BNL 22998 TEMPORAL VARIATION OF SUSPENDED ATMOSPHERIC

June 1977 PARTICULATES AT UPTON, L.I., N.Y.

S. SethuRaman and R. M. Brown

Presented at the Joint Conf. on Applications on Afr Pollution

Meteorology, Salt Lake City, Utah, Nov. 28-Dec. 2, 1977.

BNL 22999

PRECIPITATION COMPOSITION: NORTHEASTERN UNITED STATES

June 1977

Edward N. Ziegler

Chapter in Advances in Environmental Sciences and Engineering,

Gordon \& Breach Science Publishers, Inc. (in press).

BNL 23041 DEVELOPMENT AND CHARACTERISTICS OF INTERNAL

July 1977 BOUNDARY LAYERS DURING ONSHORE FLOWS

Gilbert S. Raynor, Robert M. Brown, and S. SethuRaman

Presented at the 58th Annual Meeting of the American

Meteorological Society, Savannah, Ga., Jan. 30-Feb. 2, 1978,

and to appear in the proceedings.

BNL 23078 BEHAVIOR OF CONDITIONED VARIABLES IN FREE TURBULENT SHEAR FLOWS

Edward E. O'Brien and Cesar Dopazo

Presented at the Symp. on Turbulence, Berlin, Germany, Aug. 1-5, 1977. To appear in Lecture Notes in Physics, ed.' by H. E. Fiedler, Berlin, Springer-Verlag.

BNL 23103

DETERMINATION OF ATMOSPHERIC GASEOUS

Aug. 1977

AND PARTICULATE SULFUR COMPOUNDS

Roger L. Tanner, Joseph Forrest, and Leonard Newman

Chapter in Sulfur in the Environment, ed. by Jerome Nriagu,

New York, John Wiley \& Sons, 1978. 
Publications

Atmospheric Sciences Division

1977

BNL 23146

STATISTICAL CORRELATIONS OF THE WAVE-INDUCED

Aug. 1977

ATMOSPHERIC TURBULENCE OVER THE SEA

S. SethuRaman

Presented at the Fifth Conf. on Probability and Statistics in Atmospheric Sciences, Las Vegas, Nev., Nov. 15-18, 1977.

BNL 23147

RELAXATION OF INITIAL PROBABILITY DENSITY FUNCTIONS IN

Aug. 1977

THE TURBULENT CONVECTION OF SCALAR FIELDS

Cesar Dopazo

Presented at the Workshop on Probability Density Function

Methods in Turbulent Flows, Lehrstuhl Fur Technische

Thermodynamik, Aachen, West Germany, Aug. 29-Sept. 2, 1977.

BNL 23179

AN INDUCTION-TYPE BIVANE TO MEASURE VERTICAL

Aug. 1977

AND LATERAL WIND VELOCITY FLUCTUATIONS

Abstract

S. SethuRaman and W. A. Tuthill

Presented at the Fourth Symp. on Meteorological Observations and Instrumentation, Denver, Colo., Apr. 10-14, 1978.

BNL 23180

MEASUREMENT OF VERTICAL VELOCITY FLUCTUATIONS IN THE

Aug. 1977 ATMOSPHERIC BOUNDARY LAYER WITH A SMALL AIRCRAFT

Abstract

S. SethuRaman, R. M. Brown, and G. S. Raynor

Presented at the Conf. on Atmospheric Measurements using Aircraft, Denver, Colo., Apr. 10-14, 1978. 
Publications

Atmospheric Sciences Division

1977

BNL 23184

Aug. 1977

A FEW PROBLEMS AND TECHNIQUES IN TURBULENT REACTIVE SYSTEMS

Cesar Dopazo

Presented at the Sixth Intern. Colloquium on Gasdynamics of

Explosions and Reactive Systems, Royal Inst. of Tech.,

Stockholm, Sweden, Aug. 22-26, 1977.

BNL 23266

A STUDY OF THE MECHANISMS OF THE - DEVELOPMENT

Sept. 1977 OF WIND GENERATED CURRENTS IN OCEANS

Abstract

S. SethuRaman

Presented at the Tenth Int'1 Liege Colloquium on Ocean Hydrodynamics, Liege, Belgium, May 8-12, 1978.

BNL 23276

Sept. 1977
AN EFFICIENT INTRACAVITY LASER RAMAN SPECTROMETER

Michael Hercher, William Mueller, Stanley Klainer (Block Engineering, Inc., Cambridge, Mass.), Robert F. Adamowicz, Ronald E. Meyers, and Stephen E. Schwartz, Brookhaven National Laboratory

J. Applied Spectroscopy (In press)
BNL 23280

Sept. $197 \%$
CHEMICAL COMPOSITION CORRELATIONS OF SULFATE AS A KUNC'IIUN UF' FARTICLE SIZE IN NEW YORK CITY AEROSOL

Roger L. Tanner, William H. Marlow, and Leonard Newman Presented at the Symp. on Atmospheric Sulfur Compounds: Formation and Removal Processes, AIChE 70th Annual Meeting, New York City, Nov. 13-17, 1977. 
Publications

Atmospheric Sciences Division

1977

BNL 23281

Sept. 1977

Abstract
AN OCEAN TRANSPORT MODEL FOR ASSESSING POLLUTION HAZARDS TO COASTAL REGIONS

A. G. Tingle and D. A. Dieterle

Presented at the 58th Annual Meeting of American

Meteorological Society, Savannah, Ga., Jan. 30-Feb. 2, 1978. To appear in the proceedings.
BNL 23283

Sept. 1977
VARIATION OF SEA SURFACE TEMPERATIIRFIS

IN A BAY INLET-OCEAN REGION

Mark D. Powell and S. SethuRaman

Submitted for journal publication
BNL 23284

Sept. 1977
CHEMICAL COMPOSITION AND SIZE DISTRIBUTTON OF SULFATE AS

A FUNCTION OF PARTICLE SIZE IN NEW YORK CITY AEROSOL

Roger Tanner, Rohert Sarber, William Marlow (BNL);

Brian Leaderer, Yale University; Delbert Eatough,

Brigham Young Univ., and Marie Ann Leyko, New York University

Presented at the American Industrial Hygiene Assn., Annual

Meeting Joint Aerosol Technology-Air Pollution Session,

New Or1eans, La., May 26, 1977.
BNL 23314

Sept. 1977
RANDOM ADVECTION OF CHEMICALLY REACTTNG SPECIES

Ronald E. Meyers, Fdward F. O'Brien, and L. Ridgway Scott

J. of Fluid Mechanics (in press for March 1978)
BNL 23332

Sept. 1977

Abstract
STRUCTURE OF TURBULENCE IN THE ATMOSPHERIC

SURFACE LAYER DURING HIGH WIND EPISODES

S. SethuRaman

Presented at the Third U.S. National Conf. on Wind Engineering

Research, Gainesville, Florida, Feb. 26-March 1, 1978. 
Publications

Atmospheric Sciences Division

1977

BNL 23347

SULFATE-SULFUR DIOXIDE RELATIONSHIPS DURING DA VINCI FLIGHTS

Oct. 1977

Joseph Forrest and Leonard Newman

Presented at the American Geophysical Union Meeting Special

Session on Project Da Vinci, San Francisco, Calif., Dec. 5-9, 1977.

BNL 23367

Oct. 1977

Abstract
THE FATE OF HS RADICAL UNDER ATMOSPHERIC CONDITIONS

Mark W. Thiemens (Dept. Oceanography, Florida State Univ., Tallahassee, Florida) and Stephen E. Schwartz, BNL

Presented at the Atmospheric Photochemistry Symp. of the 13th

Informal Photochemistry Conf., Tampa Fla., January 4-7, 1978.
BNL 23385

Oct. 1977
TRENDS IN ATMOSPHERIC PARTICULATE CONCENTRATION AT A LOCATION IN THE NORTHEAST UNITED STATES

Robert M. Brown and S. SethuRaman

Presented at the Fourth Joint Conf. on Sensing of Environmental Pollutants, New Orleans, La., November 6-11, 1977. To appear in the Preprint Volume.
BNL 23393

Informa1 Report
USER'S GUIDE FOR THE IMPLEMENTATION OF LEVEL ONE OF THE PROPOSED AMERICAN NATIONAL STANDARD SPECIFICATIONS FOR AN INTORMATION INTERCHANCE DATA DESCRIPTIVE FILE ON CONTROL DATA 6000/7000 SERIES COMPUTERS

Richard A. Wiley and Carmen Benkovitz
BNL 23404

Oct. 1977

Abstract
SOME MICRO-METEOROLOGICAL OBSERVATIONS DURING THE APPROACH AND PASSAGE OF HURRICANE BELLE

S. SethuRaman

See BNL 23638 
Publications

Atmospheric Sciences Division

$\begin{array}{ll}\text { BNL 23441 } & \text { APPLICATION OF COMPUTER-DRIVEN DISPLAYS TO SODAR SYSTEMS } \\ \text { Dec. } 1977 & \text { John P. Scheib } \\ \text { Abstract } & \text { See BNL } 23631\end{array}$

Abstract See BNL 23631

BNL 23442 FINITE ELEMENT SOLUTION FOR TURBULENT

Oct. 1977 GECOND ORPER CLOSURE SCHEME

Abstract Hsi-Nan Lee

Presented at APS Div. Fluid Dynamics 30th Anniversary

Meeting, Bethlehem, Penna., Nov. 21-23, 1977.

BNL 23551 VARIABILITY OF SOLAR RADIATION WITH GEOGRAPHICAL LOCATION

Nov. 1977 C. Nagle and S. SethuRaman

Presented at the Second National Solar Radiation Data

Workshop, Skyland, Virginia, Sept. 26-28, 1977.

BNL 23631 APPLICATION OF COMPUTER-DRIVEN DISPLAYS TO SODAR SYSTFMS

Dec. 1977 John P. Scheib

Presented at the Fourth Symposium on Meteorological Observations and Instrumentation, April 10-14, 1978, Denver, Colo. To appear in the Preprint Volume.

BNL 23632

AN INDUCTION-TYPE BIVANE TO MEASURE VERTICAL

Dec. 1977 AND LATERAL WIND VELOCITY FLUCTUATIONS

E. EcthuRaman and W. A. Tuthill

Presented at the Fourth Symposium on Meteorological Observations and Instrumentation, April 10-14, 1978, Denver, Colo. To appear in the Preprint Volume. 
Publications

Atmospheric Sciences Division

1977

BNL 23633

MEASUREMENT OF VERTICAL VELOCITY FLUCTUATIONS IN THE

Dec. 1977 ATMOSPHERIC BOUNDARY LAYER WITH A SMALL AIRCRAFT

S. SethuRaman, R. M. Brown, G. S. Raynor and W. A. Tuthil1 .

Presented at the Fourth Symposium on Meteorological Observations and Instrumentation, April 10-14, 1978, Denver, Colo. To

appear in the Preprint Volume.

BNL 23638

Nov. 1977
SOME MICRO-METEOROLOGICAL OBSERVATIONS DURING THE APPROACH AND PASSAGE OF HURRICANE BELLE (1976)

S. SethuRaman

Presented at AMS 11th Tech. Conf. on Hurricanes and Tropical Meteorology, Miami Beach, Florida, December 13-16, 1977.
BNL 23672 Dec. 1977
CHEMICAL COMPOSITION OF SULFATE AS A FUNCTION OF PARTICLE SIZE IN NEW YORK SUMMER AEROSOL

Roger L. Tanner, Robert Garber, William Marlow, Brian Lederer, and Marie A. Leyko

Presented at the American Industrial Hygiene Assoc. Meeting, New Orleans, Louisiana, May 22-27, 1977.

Annals of New York Academy of Sciences (in press)
BNL 50649

March 1977

Formal

Report
A NUMERICAL OIL TRAJECTORY FORECAST MODEL USED TO ASSESS THE HAZARD TO LONG ISLAND BEACHES FROM OIL ENTERING THE N.Y. BIGHT APEX FROM FEBRUARY 11-24, 1977

A. G. Tingle and D. A. Dieterle 
Publications

Atmospheric Sciences Division

1977

BNL 50651

A COMPUTER ANALYSIS OF THE SPREAD OF POLLUTION

May 1977 LONG ISLAND BEACHES (July 1976)

Formal

Report

Arthur G. Tingle 
Land and Freshwater Environmental Sciences Group

George R. Hendrey

Leader

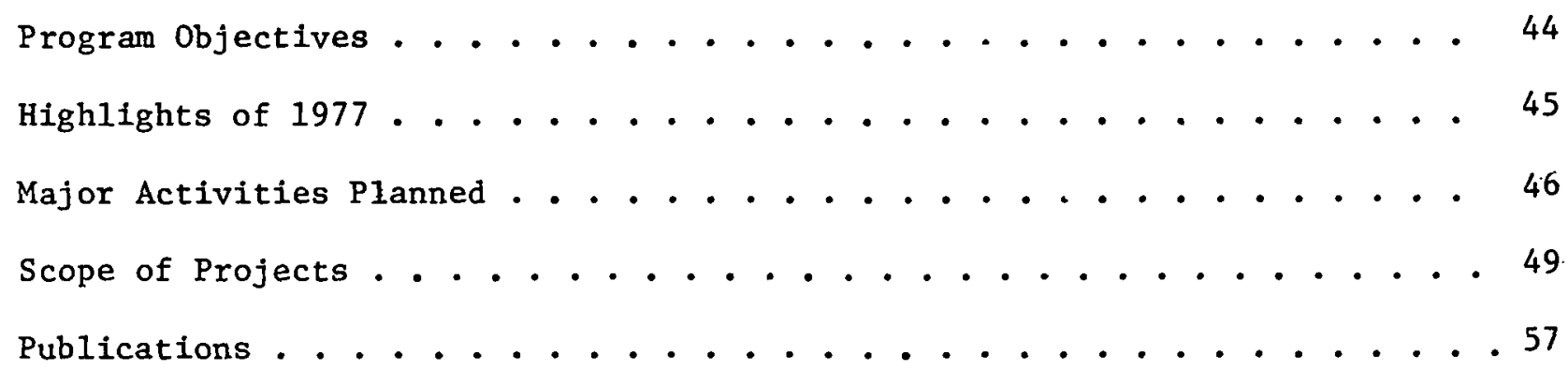


IV. Land and Freshwater Environmental Sciences Group

\section{A. Program Objectives}

In order to provide a comprehensive, coordinated assessment of the actual or potential impacts of man's activities on both terrestrial and freshwater ecosystems, a multidisciplinary team has been assembled in the Land and Freshwater Environmental Sciences Group. Specialists in the fields of limnology, terrestrlal ecology, plant sciences, bacteriology, virology and systems eng1neering are included. The Group also interacts closely with consultants from other academic institutions.

The objectives of the Group's current research projects are to:

1. Describe llie cliemlsity of precipitation at the BNL site and its relationship to other variables such as duration of event (short-interval sampling) and both mesoscale and synoptic scale meteorological events.

2. Assess the effects of energy-related pollutants on precipitation chemistry at the BNL site.

3. Determine whether or not energy-related atmospheric pollutants cause injury to selected species of forest and fleld crop plants and to describe the nature of injuries observed.

4. Determine the effects of energy-related atmospheric pollutants on soil microblota, especially khizobium, and to assess potential impacts of these pollutants on the Interaction of Rhizobium with leguminous plants.

5. Contribute to the development of prognostic models of the effects of energy related atmospheric pollutants on forest and field-crop growth, yield and value.

6. Develop and evaluate the use of artificial wetlands, or modified natural wetlands, for the renovation of wastewater from intermediate-sized communities.

7. Develop a manual describing both the biological processes and engineering methods necessary for using wetlands as an appropriate technology for the renovation of waste water. 
8. Evaluate the effectiveness of various waste water renovation systems in removing viruses.

9. Provide local and regional officlals with information concerning the virus content of waste waters and receiving waters, for use in long-range water resource planning.

10. Provide an ecological characterization of the BNL site and facilities preliminary to the possible establishment of a National Environmental Research Park.

\section{B. Highlights of 1977}

One full year of precipitation chemistry and meteorological data was obtained. Sulfate, nitrate and $\mathrm{pH}^{+}$concentrations were highest in summer, lowest in winter and, generally, varied in parallel. Nitrate concentration appeared to increase during thunder storms.

Improvements were made in chambers for exposing plants to artificial rain and aerosols. A variety of forest and fleld crop plants showed leaf lesions or gamete inhibition at chemical concentrations similar to those in ambient rainfall. Under certain experimental conditions, some plants were found to be unaffected or enhanced by dry ammonium sulfate aerosols well in excess of ambient concentrations, or free of visible leaf injury at acid rain $\mathrm{pH}$ levels as low as 3.1 .

Laboratory studies of agricultural and forest solls indicated that acid rain can increase the amount of $\mathrm{N}_{2} \mathrm{O}$ released to the atmosphere as a consequence of Inhibition of denitrification in these soils.

Aeroponic culture studies indicated a strong inhibition of root development, nodulation, rhizobial infection and rhizobial nitrogen fixation at less than $\mathrm{pH} 5.6$.

A simulation model of competitive growth among five tree species in a mixed forest was constructed. Based on assumed levels of leaf injury and photosynthetic inhibitions due to acid rain, the model indicated that inhibition of forest growth was not significant at damage levels of up to $20 \%$ of leaf surface, although individual species were Inhibited. 
Data gathered from the operation of an artificial wetland for the renovation of wastewater demonstrated the efficacy of these systems in renovating waters to near drinking water standards.

Methods for sampling, concentration, and analysis of human viruses, were developed and the penetration of polio virus through soils and recharge basins to groundwater aquifers was described.

The ability of human viruses and bacterlal pathogens to survive in treatment ponds and the virus-removing efficiencies of selected wastewater treatment systems located in Nassau and Suffolk Counties were assessed. Human virus content of surface waters including lakes, creeks, marine embayments (Including shellfish) were assessed and the 208 sub-project was completed with a report released by The Nassau-Suffolk P1 anning Cnmmission.

Description of aspects of the terrestrial and aquatic ecology of several areas within the BNL site was begun with observational and experimental studies being carried out by graduate students. Activities include a small mammal census, vegetational analyses of forest sites, soll surveys and inventory of fresh-water organisms.

C. Major Activities P1anned

Full analysis of precipitation and meteorological data will be carried out following the collection of two years of data from the automated short-interval precipltation collector.

The effects of acld rain on plants via the root-soil system will be tested in both greenhouse and field experiments by application of artificial acid rain to the soil only.

The effects of acid rain on plant morphogenesis in a field crop of soybeans will be tested by spray-application to the whole plant.

A handbook of ecosystem engineering will be completed, describing the use of wetlands for wastewater renovation.

Experimental mini-marsh systems will be constructed in order to expose individual wetland components to a variety of experimental treatments.

Experiments on the interaction of viruses with soils, rainwater and artificial wetlands will be extended. 
Seasonal effects on viruses and their interactions with naturally occurring microflora will be studied.

Ecological characterization of undisturbed areas at the BNL site will continue and studies of population interactions will begin.

Effects of acid precipitation on aquatic ecosystems will be studied at field sites in the Adirondack Mountains. 
ว

THIS PAGE

\section{WAS INTENTIONALLY LEFT BLANK}


D. Scope of Projects 
Title: Effects of Acid Rain on Terrestrial Ecosystems

FY 77: $\$ 215,000$

FY 78: $\$ 250,000$
Principal Investigator(s):

G. R. Hendrey, A. J. Francis,

G. Raynor, L. Evans

Sponsor: Division of Biomedical and Environmental Research/DOE

Preclpitation is collected by a sequential sampler at 5-min. to 1-hr. intervals and analyzed chemically. Relationships to meso- and synopticscale meteorology, and mechanisms of pollutant "scrubbing" by precipitation are studied. Data is provided for air pollution transport model verification and to the MAP3S network.

A variety of Northeastern forest and field-crop plants are exposed in environmental chambers to artificial acid rain, and ensuing damages are observed. The adaxial leaf surface was the more severely affected with lesion formation occurring mostly near stomata and vascular tissues. The effects of precipitation composition on gametophyte sperm motility was also examined; chloride, nitrate, and sulfate at concentrations equivalent to rainwater caused up to $60 \%$ reduced motility. Effects on forests are modeled and a cooperative study to model damages to field crops is planned. Rhizobium symbiosis with legumes is intensively studied. Various stages of root growth, nodulation, infection, and nitrogen fixation were inhibited by moderately acidic conditions. Preliminary tests indicate that Rhizobium leguminosarum is intolerant of low $\mathrm{pH}$, that its infectiousness is reduced below $\mathrm{pH} 4.8$, and its $\mathrm{N}$-fixing effectiveness is decreased below $\mathrm{pH} 5.6$.

Soils acidified by artificial acid rain release significant amounts of $\mathrm{N}_{2} \mathrm{O}$. The distribution of free-living nitrogen-fixing bacteria in acid forest soils is low and nitrogen gain by asymbiotic bacterial fixation is thus acid-inhibited. 
Title: Ecosystems Engineering

FY 77: $\$ 75,000$

FY 78: $\$ 75,000$
Principal Investigator(s):

M. M. Small

Sponsor: Rockefeller

Foundation

A manual describing the construction and operation of artificial wetland ecosystems for the renovation of wastewater is being developed. The handbook is designed for wastewater engineers, water quality regulatory agencies, environmental science teachers and students, and citizen's advisory groups interested in building low-energy systems to treat domestic sewage and septage through use of semi-closed, artificial wetland ecosystems. Treatment of industrial and utility wastes will not be considered.

The major portion of the manual will present procedures for designing and building wetland systems that will recycle sludge and renovate water to either effluent or drinking water standards, depending on the rechargeability and size of the natural recharge area following the system. The design approach will combine principles of engineering and ecology. It will enable designers to understand principles of nutrient uptake and adsorption by the different components of the system, the biotic and abiotic factors, and accompanying hydrologic and engineering considerations.

The components, or nutrient sinks, to be dealt with are: (1) wetland meadows, similar to overland flow treatment; (2) marshes of varying depths and design; and (3) ponds, either alone or as combined marsh-ponds. Design specifications will be based on data analysis from Brookhaven's two experimental meadow/marsh/pond systems; regional pilot studies; and work done elsewhere on wetland systems treating sewage. 
Title: Fate of Human Viruses in Groundwater Recharge Systems Utilizing Tertiary Treated Effluent

FY 77: $\$ 100,000$

FY 78: $\$ 106,000$
Principal Investigator(s):

J. Vaughn

Sponsor: Environmental

Protection Agency

Numerous questions have arisen concerning the overall safety of wastewater reuse procedures as a result of the inability to determine the fate of human viruses in such systems. Programs previously undertaken to ascertain this information have been subject to the following shortcomings: (1) data have been derived principally from laboratory-scale studies with questionable applicability to large-scale operations, (2) studies conducted at field sites have often incorporated use of non-human viruses (i.e. bacteriophage) or bacterial species, with extrapolation of resulting data to the human virus situation being inappropriate, (3) many studies which have dealt with human viruses occurring in field systems were conducted previous to the development of satisfactory technologies for sampling viruses from large volumes of water.

The present study utilizes a unique experimental recharge facility designed and maintained by the U.S. Geological Survey in Medford, Long Island. The facility combines the benefits of "real world" recharge operation with an experimentally controllable system. Using this facility, 1t will be the objective of this study to assess and evaluate the human virus removing capabilities of a groundwater recharge system utilizing tertiary treated effluent, and its overall ability to return virologically acceptable water to the groundwater aquifer. 
Title: The Fate of Human Viruses in a Land Application Wastewater Treatment System

FY 77: $\$ 50,000$

FY 78: $\quad \$ 50,000$
Principal Investigator(s):

J. Vaughn

Sponsor: Rockefeller Foundation

Little information is presently available regarding the fate of human microbial pathogens in overland flow or other land application systems. The present study will attempt to shed some light on the question by a program of routine field analyses supplemented with limited laboratory and field experimentation.

While the main emphasis of the project is the fate of viruses, studies will be undertaken to determine the impact of bacterial organisms (i.e. coliforms, Salmonella and Shigella sp.) on land treatment systems. 
Title: The Assessment of Human Virus Occurrence in Long Island Aquatic Systems

FY 77: $\$ 65,000$

FY 78: No Funding
Principal Investigator(s): J. Vaughn

Sponsor: Nassau-Suffolk Regional Planning Board

The study, which was funded under section 208 of the Federal Water Pollution Control Act Amendments of 1972 (PL 92-500), Involved the isolation, enumeration, and identification of human enterovirus from a variety of aquatic resources. Among systems tested were: marine embayments, shellfish; tributary creeks; lakes; public water supplies; groundwater aquifers under various influences (i.e. sewage recharge, stormwater recharge, sanitary landf111). The study was the first of its kind to be financed by Federal "208" funds.

Information resulting from the study is currently belng used by state and county officials involved in a 20-year plan for management of water resources on Long Island. 
Title: National Environmental Research Park

FY 77: $\$ 35,000$

Principal Investigator(s):

G.S. Raynor

FY 78: $\$ 50,000$

Sponsor: Division of Biomedical

and Environmental Research/DOE

Programs relating to the environment have been carried out at Brookhaven National Laboratory (BNL) since its inception thirty years ago. Studies in meteorology, in the movement of surface and ground water, and in terrestrial ecology were instituted to establish baselines against which potential impacts of BNL could be measured and control strategies developed. This interest in problems of the envrionment has continued and with the recent development of public concern about effects of energy-related activities, these studies have served as foci for greatly expanded efforts in the atmospheric, marine, and land and fresh water environmental sciences.

Over the years a series of unique facilities have been conceived, designed, and constructed for the study of the environment. These often involved large areas of land and incorporated expensive equipment and instrumentation.

In the interest of promoting research and study in the environmental sciences on the part of qualified investigators at educational and research institutions in the Northeast, it is planned to establish a National Environmental Research Park (NERP) at BNL that will provide an agency for making these facilities available on a cooperative basis. The cost, complexity, and space requirements would otherwise put these facilities beyond the reach of most of these institutions. 


\section{THIS PAGE}

\section{WAS INTENTIONALLY LEFT BLANK}


E. Publications 
Publications

Land and Freshwater Environmental Sciences Group

1977

BNL 22975R EFFECT OF BUFFERED SOLUTIONS AND VARIOUS ANIONS ON VEGETATIVE

June 1977 AND SEXUAL DEVELOPMENT IN GAMETOPHYTES OF PTERIDIUM AQUILINUM

Lance S. Evans and Donna M. Bozzone

Canadian $\mathrm{J}$. of Botany (in press April 1978)

BNL 22996R FOLIAR RESPONSE OF SIX CLONES OF HYBRID POPLAR

July 1977 TO SIMULATED ACID RAIN

Lance $\varepsilon$. Evano, Nioholas b'. Gmur and Filnmena na Cinst:

Phytopathology (in press)

BNL 23063 ON THE DEVELOPMENT OF A TECHNIQUE FOR MEASUREMENT

July 1977 OF BIOGENIC SULFUR EMISSION FLUXES

F. B. Hill, F. W. Barvenik (BNL), V. P. Aneja (Northrop Services, Inc.), and R. M. Felder (North Carolina State Univ.)

Presented at the AIChE 70th Meeting, New York City, Nov. 13-17, 1977.

BNL 23302

EFFECTS OF SOLUTIONS TO SIMULATE ACIDIC PRECIPITATION ON

Sept. 1977

FERTILIZATION OF THE BRACKEN FERN (PTERIDIUM AQUILINUM)

Lance S. Evans and Donna M. Bozzone

Presented at the National Environmental Research Park Symp., Los Alamos, New Mexico, Aug. 15-16, 1977.

BNL 23303

Sepl. $19 \%$

Abstract
LOW ENERGY WASTEWATER TREATMEN'I

Maxwell M. Small

Presented at the Second National Conf. on Technology for Energy Conservation, Albuquerque, New Mex1co, Jan. 23-27, 1978. 
Publications

Land and Freshwater Environmental Sciences Group

1977

BNL 23688

A PLANT DEVELOPMENTAL SYSTEM TO MEASURE THE

Dec. 1977 IMPACT OF POLLUTANTS IN RAIN WATER

Donna M. Bozzone and Lance S. Evans

Submitted for journal publication

BNL 50630

NATURAL SEWAGE RECYCLING SYSTEMS - January 1977

May 1977

Maxwel1 Smal1

Formal

Report

BNL 50675

July 1977

Forma1

Report
DATA REPORT - MEADOW/MARSH/POND SYSTEM

April 1977

Maxwell Small and Christopher Wurm
BNL 50775

(in press)

Forma1

Report
THE 1977 BREEDING BIRD CENSUSES AND VEGETATIONAL SURVEYS IN TWO SUCCESSIONAL STAGES OF OAK-PINE FOREST

Gilbert S. Raynor, John J. Rusclca, James H. Clinton and David L. Larsen

BNL 50786 ACID RAIN RESEARCH PROGRAM - ANNUAL PROGRESS REPORT

(in press) July 1976 THROUGH September 1977

Formal

Report

Lance S. Evans, A. J. Francis, and G. Raynor

BNL 50787 DATA REPORT - AN ASSESSMENT OF THE OCCURRENCE OF HUMAN

(in press) VIRUS IN LONC ISLAND AQUATIC SYSTEMS

Formal

J. M. Vaughn and E. F. Landry

Report 
TIIIS PAGE

\section{WAS INTENTIONALLY LEFT BLANK}


V.

Oceanographic Sciences Division

John J. Walsh

Division Head

Program objectives . . . . . . . . . . . . . . . . . 62

Highlights of 1977 . . . . . . . . . . . . . . . . 6 63

Major Activities Planned . . . . . . . . . . . . . . . . . 64

Scope of Projects . . . . . . . . . . . . . . . . . . 67

Publications . . . . . . . . . . . . . . . . . . . . 79 
V. Oceanographic Sciences Division

A. Program Objectives

To provide a quantitative assessment of the impact of present and future energy demands of the Northeast region on adjacent coastal zones, the objectives of the multidisciplinary research team within the Oceanographic Sciences Division are:

1. Assess natural sources of variability of food chain components of the continental shelf in order to distinguish between the effects of man-related and natural perturbations.

2. Provide a unique data base on dynamic ecological processes that link primary production to higher trophic levels and man.

3. Link meteorological (in cooperation with the Atmospheric Sciences Division) and physical studies of the coastal habitat to the transport and diffusion of energy related pollutants and planktonic organisms.

4. Study food chain alterations as a function of species replacement in response to past and present perturbations at climatological, seasonal, and weekly time scales.

5. Analyze the importance of larval survival of zooplankton and ichthyoplankton in relation to increased mortalities of this life stage and future oscillations of the living resources of the northeast continental shelf.

6. Distinguish the importance of local oscillations of the New York Bight ecosystem in comparison with import from longshore transport of organisms and pollutants from the upstream areas of Georges Bank and the Gulf of Maine.

7. Refine quantitative simulation models of the energy flow within coastal ecosystems of the Mid-Atlantic Bight (Cape Hatteras-Nova Scotia), upwelling regions (Peru, Northwest Africa, Oregon-California), and the Bering Sea to provide a comparative analysis of the relative resiliency of these systems to energy related and natural perturbations. 
8. Continue to coordinate the Department of Energy funded research in the northeast and to collaborate with other federal agencies (National Oceanic Atmospheric Administration-Marine EcoSystems Analysis Program; NOAA-National Marine Fisheries Service, Environmental Protection Agency, U.S. Coast Guard) and universities (State University of New YorkStony Brook, SUNY-Albany, Lamont-Doherty, Bigelow Laboratory, Woods Hole Oceanographic Institution, Argonne National Laboratory) in field, laboratory, and theoretical studies of the northeast continental shelf.

B. Highlights of 1977

Predicted the trajectory of oil spills in the Hudson River and on Nantucket Shoals.

Initiated analysis of the physical and biological causes of a $\$ 60$ million fish kill within the New York Bight.

Determined the importance of storms in resupplying nutrients to the northeast continental shelf.

Completed a series of cruises on the spring-summer conditions of the food chain within the New York Bight.

Successfully deployed the 4-buoy current meter, line of sight telemetry system south of Long Island in a study of spring physical dynamics of the coastal boundary layer.

Obtained a one month time series of chlorophyll measurements sampled every 5 minutes with an in situ fluorometer during summer stratified conditions.

Established the feasibility of $P_{700}$ ( $c h 1$ a ratios) to estimate vertical mixing within the water column.

Assessed the importance of bacteria and benthos in nutrient recycling on the continental shelf.

Obtained diel time series of zooplankton distribution, gut content, and feeding rate with a high-yield pump, fluorometry, and particle counter. 
Determined feeding threshold of flounder larvae within the New York Bight.

Completed a two year field study of the Peru upwelling ecosystem.

Initiated a model of larval fish survival within the Bering Sea.

Hosted the First Annual DOE Contractor's Meeting.

Initiated a joint study of larval herring survival on Georges Bank and of yellowtail flounder larvae in the New York Bight with NOAA-NMFS.

C. Major Activities Planned

Complete analysis of the importance of climatology, speeies succession, differential grazing, and urban wastes in oxygen depletion within the Middle Atlantic Bight.

Complete winter and summer studies of the physical dynamics of the coastal boundary layer with simultaneous deployment of the in situ fluorometer system.

Examine the longshore coupling and utilization of the spring bloom between Georges Bank and the New York Bight in a joint USSR/US effort.

Host a meeting on secondary production of the northeast continental shelf (University of Miami, Lamont-Doherty Observatory, University of Rhode Island, BNL, Woods Hole Oceanographic Institution, Bigelow Laboratory, National Marine Fisheries Service-Woods Hole, Narragansett, Sandy Hook Laboratories, and Bedford Institute of Oceanography).

Continue studies of perturbation of the energy transfer from phytoplankton to zooplankton, larval fish, and benthos.

Initiate a study of carbon fractionation and vertical mixing as part of an analysis of the uptake of carbon dioxide by the continental shelf.

Initiate a sensitivity analysis of the northeast coastal ecosystem to proposed energy-related activities.

Complete a study of sediment transport off Long Island with NOAAAtlantic Oceanographic Meteorological Laboratory. 
Complete a larval herring study on Georges Bank with NOAA-NMFS.

Host the Second Annual DOE Northeast Contractor's Meeting.

Complete construction of the satellite telemetry system, offshore buoy, and computer link to NOAA-National Weather Service. 
‘

\section{THIS PAGE}

WAS INTENTIONALLY

LEFT BLANK 
D. Scope of Projects 
Title: Northeast Oceanography Coordination

FY 77: $\$ 25,000$

Principal Investigator:

F.W. Barvenik

FY 78: $\$ 25,000$

Sponsor: Division of Biomedical

and Environmental kesearch (DOE)

The DOE-funded oceanographic programs in the northeast include a diverse array of facilities, talents, and research objectives, and are located at geographically-dispersed 1aboratories and universities. The environments under study range from the open ocean, continental slope and shelf, estuaries, bays, and coastal lagoons to the intertidal zone, with particular strength in the study of estuarine and shelf ecosystems. The expertise and current research of the investigators include physical, chemical, and geological oceanography, several specialities within biological oceanography, and ecosystems analysis, with emphasis on the shelf and estuarine systems.

In order to maximize the usable output from these programs, a high degree of coordination and communication among the investigators and with other tederally-funded programs in the northeast is desirable.

Using three types of meetings as primary mechanisms, Brookhaven National Laboratory (BNL) proposed to encourage better information exchange and liaison among the northeast DOE contractors. These meetings will include: 1) Annual program-review meetings among this entire group of contractors; 2) meetings and/or experiments for the intercomparison of methods and instruments; and 3) meetings on single topics of timely nature. Reports from these meetings will be made available to DOE for the periodic reevaluation of program goals, deficiencies, and accomplishments. 
Tilte: Oceanography Ship Charter

FY 77: $\$ 208,000$

Principal Investigator:

F.W. Barvenik

FY 78: $\$ 200,000$

Sponsor: Division of Biomedical and Environmental Research (DOE)

Research vessels are required for multidisciplinary studies of coastal oceanography at Brookhaven National Laboratory (BNL). This research includes projects on Ecosystem Analysis, Primary Productivity and Utilization, Food Chain Dynamics, Larval Fish, Coastal Transport and Diffusion, and Mid-Atlantic Bight Coordination. The closely associated Coastal Meteorology and Instrumentation Development programs also require vessel support.

Vessel requirements are based on the nature, location, and timing of the scientific work to be conducted. Shelf and shelf break biological-process cruises involve the investigation of biological, chemical, and physical phenomena and require cooperative effort among scientists representing the several disciplines. The resulting need for a large scientific complement together with a stable oceanographic platform during adverse conditions generally leads to the requirement for one or more large vessels. The well-equipped major vessels of the University National Oceanographic Laboratory System (UNOLS) meet these requirements and have been very effectively utilized. In addition, cooperative use of National Oceanic and Atmospheric (NOAA) vessels has proved to be feasible and advantageous to both agencies.

Vessels are also required for inshore biological-process investigations near the COBOLT current-meter array, nearshore physical oceanography cruises associated with the COBOLT experiment, and nearshore meteorology field work in support of the coastal meteorology program. These operations are carried out by the BNL-operated LCM and R/V COBOLT plus the charter of other small research vessels. Charter of the LCU operated by the U.S. Naval Underwater Systems Center has provided an effective support for the current-meter buoy program. 
Title: Food Chain Dynamics

FY 77: $\$ 375,000$

Principal Investigator:

M. J. Dagg

FY 78: $\$ 375,000$

Sponsor: Division of Biomedical and Environmental Research (DOE)

The goal of this program is an understanding of coastal trophic-dynamics, as affected by natural stimuli and anthropogenic perturbations. This knowledge includes the differentiation of responses of heterotrophic planktonic populations to natural and man-caused events and a description of the ultimate effects of these events on the transfer of energy between trophic levels. Continental-she1f waters are subject to high daily, weekly, and seasonal stimuli and may be subject to high-amplitude energy-related perturbations in the future, such as offshore nuclear reactors and oil fields. Fish larvae and zooplankton are both components of the coastal ecosystem which are extremely vulnerable to damage by entrainment in heat exchangers, by oil pollution, and by critical limitation of food supply.

Mesoscale seasonal and geographical variations in coastal ecosystems are now reasonably well described, but the small-scale and short-term processes which appear to immediately control zooplankton community structure and dynamics remain poorly understood. An understanding of these processes of secondary production requires an integrated field program encumpassing physical parameters, phytoplankton production and physiology, zooplankton and ichthyoplankton behavior, growth and survival, and nutrient regeneration by bacteria, benthos, and the other higher trophic levels. Intensive ecosystem studies of a variety of coastal habitats coordinated with laboratory experimentation will provide the basis for predictive models and the evaluation of potential effects of human activities in the coastal environment. 
Title: Primary Production and Utilization

FY 77: $\$ 430,000$

FY 78: $\$ 430,000$
Principal Investigator:

P. Falkowski

Sponsor: Division of Biomedical and Environmental Research (DOE)

The Primary Production and Utilization Program is designed to provide basic quantitative information on the primary producers and their utilization by the dominant herbivores in the context of the dynamics of the New York Bight ecosystem. Such information is necessary in order to understand the regulating and"controlling factors for primary and secondary productivity in the coastal shelf waters and the mechanisms by which the significant factors work in the ecosystem. Without this understanding, the assessment and prediction of the effects of energy-related activities on the continental shelf will not be possible. Basic information on the effects of light (quality and quantity) and nutrients on phytoplankton growth ultimately can relate to the structure and function of phytoplankton communities. The disruption of timing and composition of the primary producers by energyrelated perturbations would have effects on the structure and function of zooplankton communities. The mechanisms for this response can also be partially evaluated in 1aboratory situations. To relate laboratory-derived information to the ocean, it is necessary to use temporal and spatial scales relevant to the phytoplankton and zooplankton. The system selected is oriented around this approach. Biological instrumentation is being developed that ultimately will permit continuous, real-time evaluation of slgnificant variables. 
Title: Coastal Transport and Diffusion

FY 77: $\quad \$ 450,000$

Principal Investigator:

T. S. Hopkins

FY 78: $\$ 450,000$

Sponsor: Division of Biomedical

and Environmental Research (DOE)

The goal of this project is to understand the processes of transport and diffusion as they relate to the possible environmental effects of energyrelated activities in the Mid-Atlantic Continental Shelf region. These processes must be understood because of their direct effect on the movement of pollutants and other materials and because of the important role of circulation processes in the dynamics of shelf ecosystems. While inftial studies emphasized the coastal boundary region, present studies have increased the focus to shelf-wide problems. The research has been divided into five components: 1) Coastal Boundary Layer, 2) Shelf Circulation, 3) Water Mass Analysis, 4) Water Property Dispersion, and 5) Air-Sea Interaction. The observational phase of the original COBOLT program will be complete by the end of FY 1978. The spar-buoy telemetry system, which has been considerably improved, will then be used as an observational facility for the remaining components. Other sources of observational data come-from hydrographic cruises, an air-sea interaction buoy, the development of a deep shelf mooring, drogues, and laboratory dispersion studies. Theoretical interpretations continue to integrate physical data into coastal ecosystem models. Internal cooperation continues with the Atmospheric Sciences and Instrumentation Divisions, as does external cooperation with Woods Hole Oceanographic Institution, Bigelow Laboratory, Oregon State University, Lamont-Doherty Geophysical Observatory, and others. Within the Oceanographic Sciences Division, the project is considered an integral and essential part of the DOE multidisciplinary research program to understand the impact of energy-related activities within the Northeast Coastal Zone. 
Title: Larval Fish

FY 77: $\$ 100,000$

Principal Investigator:

J. J. Walsh

FY 78: $\$ 100,000$

Sponsor: Division of Biomedica1 and Environmental Research (DOE)

The total finfish biomass of the Middle Atlantic Bight is now $25 \%$ of the estimated virgin stocks. Differences in recruitment and size of year classes of. fish are believed to be a function of variable mortality rates during their larval phase. Thus, emphasis at Brookhaven National Laboratory (BNL) has been placed on predictive methods of determining the rate of survival of larval fish under varying environmental conditions and adult spawners. For survival of these larvae, food must fall within narrow particle-size ranges, must be above a critical concentration, and must have nutritional value adequate for further growth and development. Fish larvae in the coastal ecosystem are also extremely vulnerable to damage by entrainment in heat exchangers, by oil pollution, and by chlorine and heavy metals. Recently acquired data on the mesoscale spatial and seasonal distributions of larval fish in the New York Bight are now sufficient to permit the location, tracking, and intensive sampling of cohorts of newly-spawned larvae. However, the addiliullal determination of larval-fish growth and survival can be achieved only through a multidisciplinary approach encompassing laboratory and field measurements of all ecosystem processes impinging on the fish and their potential prey and predators. Only through such an approach can predictive models and adequate management of eventually-harvestable fish stocks be developed to distinguish between natural fluctuations and environmental deterioration. 
Title: Coastal Upwelling Ecosystems Analysis - Systems Mode1s

FY 77: $\$ 109,000$

FY 78: $\$ 173,00$
Principal Investigator:

J. J. Walsh

Sponsor: International Decade of Ocean Exploration/National

Science Foundation

Environmental problems in the coastal ocean by definition occur at the system level of complexity and require a group effort of systems analysis as an approach to their solution. Studies of total marine ecosystems were advocated over 40 years ago, but environmental problems are even greater now. The implementation of systems studies has had to await the development of an adequate technology and sufficient interest in a multidisciplinary group effort approach to oceanography. At Brookhaven National Laboratory (BNL) a research group has been assembled and has made significant progress towards the assessment of the coastal marine ecosystem. Over the past six years an enormousidata base on coastal upwelling areas has been acquired and simulation models have been used to analyze this system. The causes and consequences of ecosystem behavior are extremely difficult to identify. Solutions to problems at the systems level of complexity, such as the cause of the decline in the Peru anchovy fishery, require that data bases be readily accessible for analysis and that a significant commitment to the reduction, presentation, and interpretation of data be supported. We are thus now using simulation analysis in a comparative analysis of the perturbation response of different upwelling ecosystems off Oregon-California, Northwest Africa, and Peru. 
Title: Ecosystems Analysis in the Bering Sea - Systems Models

FY 77: -0-

FY 78: $\$ 68,000$
Principal Investigator: J.J. Walsh

Sponsor: Office of Polar Programs/ National Science Foundation

Research is examining the hypothesis that a specific combination of oceanographic factors including aspects of circulation in surface and intermediate depth water and bathymetry, coupled with the wide shallow shelf and local meteorology, promote conditions which annually favor a high production of biomass in the southeastern Bering Sea. Given this Bering Sea environment, it is proposed that the key to the success of a given year class of higher consumers (eg. the pollock) is in the sequencing of the physical and biological events. Since it is generally believed that the yearclass strength of a stock is determined during some critical phase in the early life history, usually associated with first feeding, the field effort has been specifically designed to examine the larval and juvenile phases of pollock survival within a complex matrix of associated oceanographic and weather observations. Initial simulation analysis thus considers the trajectory and larval survival of Alaska pollock from its spawning grounds within the Bering Sea. 
Title: Ecosystem Analysis of the Carbon, Oxygen, and Nitrogen Distributions within the New York Bight

FY 77: -0-

FY 78: $\$ 119,000$
Principal Investigator: J.J. Walsh

Sponsor: National Oceanic Atmospheric Administration/Marine EcoSystems Analysis (MESA)

A $\$ 60$ million fish kill occurred within the New York Bight during JuneAugust 1976 as a result of low oxygen conditions. We are constructing a simulation model to provide a quantitative ecosystem analysis of the spatial and temporal interactions of carbon, nitrogen, oxygen, phytoplankton, zooplankton, larval fish, detritus, and benthos within the New York Bight. Primary emphasis will be directed towards anoxic conditions as exemplified in the summer of 1976 with an evaluation made of the relative significance of the various sources and sinks of oxygen. Each of the significant waste inputs over which human control is possible will be assessed for their relative impact on the development of anoxia. Various wastewater management strategies can then be evaluated using this serles of simulation mudels with an assessment made of man-induced and natural perturbations of this system, 
Title: Coastal Upwelling Ecosystems Analysis - Nutrient Regeneration

FY 77: $\$ 58,000$

Principal Investigator:

T.E. Whitledge

FY 78: $\$ 82,000$

Sponsor: Internationa1 Decade of Ocean Exploration/National

Science Foundation

The Peru coastal waters have long been noted for their cold temperatures and high levels of plant and animal production, but lintil recently little effort has been devoted to zooplankton studies in this Peruvian upwelling ecosystem with virtually nothing known about their vertical distribution and migratory behavior. There has been a similar lack of experimentallyderived information on rates of ingestion of phytoplankton, excretion of plant nutrients, and respiration rates by regionally-important zooplankton. species. We are now completing analysis of a large series of zooplankton samples collected by net and pump during August-September 1976 and AprilMay 1977 off Peru. We also plan to incorporate the resulting.abundance and biomass estimates with shipboard measurements of excretion, grazing, and respiration rates of zooplankton and nekton populations to establish nutrient and food-chain budgets for the Peru upwelling system. 
Title: Ecosystems Analysis in the Bering Sea - Nutrient Fluxes

FY 77: -0-

FY 78: $\$ 88,000$

Principal Investigator:

T.E. Whitledge

Sponsor: Office of Polar Programs/

National Science Foundation

A study of nutrient inputs and distributions is being concucted as part of an investigation of the Processes and Resources of the Bering Sea Shelf (PROBES). This investigation involves nutrient excretion rates of zooplankton and nekton, the nutrient release by the sediments, and their relation to the input of regenerated nitrogen for the nitrogen requirements of phytoplankton production. The excretion data are also used to estimate ingestion rates of the zooplankton and nekton species. The ambient concentrations of nutrients are measured in all hydrographic and productivity samples and repeated sampling at a station to estimate the diel and event scales of variability in this high-latitude ecosystem. Underway mapping of near-surface nutrient concentrations, chlorophyll fluorescence, salinity, and temperature are also used to examine the spatial distribution and the relative patchiness of properties in the upper ocean. 


\section{E. Publications}


Publications

Oceanographic Sclences Division

1977

BNL 22350

Jan. 1977

Abstract
MODES OF RETURN FLOW IN LAKE ONTARIO

Jon T. Scott and Dennis R. Landsberg

Presented at the Conf. of the Midwestern Region of the

American Geophysical Union, Ann Arbor, Mich., Oct. 21-23, 1976.
DNL 22488

Mar. 1977
BACTERI INDUCED SHELL DISEASF OF T.OBSTERS (Homarus americanus)

Stewart Ma1loy

Wlldife Diseases (in preor)
BNL 22489

Mar. 1977
THE REGULATION OF NITRATE ASSIMILATION IN

LOWER PLANTS: A CRITIQUE

P. G. Falkowski

Presented at the Symp. on Nitro Metabolism in Plants, Univ. of Calif., Arrowhead Lake, Calif., Jan. 31-Feb. 4, 1977. Appearing in Nitrogen and the Environment (in press).
BNL 22523

Mar. 1977
THE NEAR SHORE FLOW FIELD SOUTH OF LONG ISLAND

Jon T. Scott

Presented at the Spring Meeting of the American Geophysical Union, Washington, D. C., May 30-June 3, 1977.
BNL 22596

Mar. 1977

Abatract
MICROBIAL AMINO ACID FLUX IN SHELF WATERS SOUTH OF LONG ISLAND DURING STRATIFIED CONDITIONS

F. W. Barvenik and S. C. Malloy

Presented at the American Society for Microbiology Meeting, New Orleans, La., May 10, 1977. To appear in the proceedings. 
Publications

Oceanographic Sciences Division

1977

BNL 22783 WIND EVENTS AND FOOD CHAIN DYNAMICS WITHIN THE NEW YORK BIGHT

May 1977

John J. Walsh, Terry E. Whitledge, Frank W. Barventk, Creighton D. Wirick, Steven 0 . Howe, BNL

Wayne E. Esaias (SUNY, Stony Brook) and Jon T. Scott (SUNY, AIbany)

Limnology and Oceanography (in press)

BNL 22784R

May 1977
THE EFFECTS OF LIGHT INTENSITY ON PHOTOSYNTHESIS AND

DARK RESPIRATION IN SIX SPECIES OF MARINE PHYTOPLANKTON

Paul G. Falkowski and Thomas G. Owens

J. Marine Biology (in press)
BNL 22974

June 1977
KINETIC PATTERNS OF MICROBIAL AMINO ACID UPTAKE

AND MINERALIZATION IN MARINE WATERS

Frank W. Barvenik and Stewart C. Malloy

Estuarine and Coastal Marine Science (in press)
BNL 23128

July 1977
NOTES ON THE BIOLOGY OF Ceratium tripos (O.F. MULLER) NITZSCH Wayne E. Esaias (Stony Brook) and Paul G. Falkowski

To appear in National Oceanographic Atmos. Admin. Professional Paper, Oxygen Depletion in the New York Bight - 1976 (in press).
BNL 23199

Aug. 1977
TOWARDS A MANAGEMENT PERSPECTIVE FOR COASTAL UPWELLING ECOSYSTEMS

Steven 0. Howe and John J. Walsh

Presented at the American Inst. of Biological Science, Tulane Univ., New Orleans, La., May 30-June 4, 1976. To appear in the proceedings Ecology and Management of the Continental Shelf. 
Publications

Oceanographic Sciences Division

1977

BNL 23440R SOME FACTORS EFFECTING POPULATION LEVELS OF THE COPEPODS

Oct. 1977 CENTROPAGES TYPICUS (KRØYER) AND PSEUDOCALANUS SP.

Michael Dagg

J. Experimental Marine Biology and Ecology (submitted)

BNT 23/R9 SEASחNAI, ANII UNSHURE-OFFSHORE VARIATIONE IN THE ABUNDANCF.

NOV. 1977 OF PLANKTONIC COPEPODS IN THE NEW YORK BIGH'I'

David C. Judkins, Creighton D. Wirick, and Wayne E. Esalas (SUNY)

Fishery Bulletin (submitted)

BNL 23818R LIGIT-SHADE ADAPTATION IN MARINE PHYTOPLANKTON: STUDIES OF

Dec. $1977 \delta$-AMINOLEVULINIC ACID DEHYDRASE FROM SKELETONEMA COSTATUM (BACILLARIOPHYCEAE)

Thomas G. Owens, David M. Riper, and Paul G. Falkowski

J. Plant Physlology (accepted) 